\title{
Examining Job Satisfaction among Kentucky Head Principals Using the Rasch Rating Scale Model
}

\author{
Xavier J. Webb, Ed.D. \\ 1925 Kingston Run Drive \\ Grove City, OH 43123 \\ Tel: (859)893-0278Ｅ-mail: xavier.webb@iq-ity.com
}

Kenneth D. Royal, Ph.D.

Tel: (919) 966-6405 E-mail: kdroyal2@ncsu.edu

John B. Nash, Ph.D.

Tel: (859) 257-7845 E-mail: John.nash@uky.edu

Received: August 12, 2015 Accepted: August 16, 2015 Published: August 16, 2015

doi:10.5296/jse.v5i3.8152 URL: http://dx.doi.org/10.5296/jse.v5i3.8152

\begin{abstract}
Effective principals can impact student learning and other vital outcomes; thus, it is important to retain effective school leaders. This article examines the perceived sources of Kentucky principals' satisfaction and dissatisfaction with their work and implications for policies and practices to increase principal retention. Survey research methods were used and Kentucky principals' satisfaction with specified job facets was measured using the Rasch Rating Scale Model (RRSM). Data indicated that head principals sampled in Kentucky were generally dissatisfied with the amount of time spent on tasks that have nothing to do with their primary responsibility of improving student outcomes.
\end{abstract}

Keywords: job satisfaction, principals, retention, K-12 education, Rasch measurement 


\section{Introduction}

From 1960 to the present, education and the role of the school principal have drastically changed due to an increase in societal, political, and economic demands to improve student achievement (Aberli, 2010; Council of Chief State School Officers, 1996; White, Brown, Hunt \& Klosterman, 2011). The shift towards accountability for student outcomes spurred what is often referred to as "effective schools research" which focuses on principals and how their role impacts the success of students (Leithwood, 1994). Researchers have consistently found that while the effects of school leadership on students are largely indirect, the principal is the key to an effective school and student success (Branch, Hanushek \& Rivkin, 2009; DeAngelis\& White, 2011; Educational Research Service, 2000; Fuller \& Young, 2009; Hallinger \& Heck, 1996; Heck \& Hallinger, 1999; Institute for Educational Leadership, 2000; Leithwood, Harris, Day, Sammons \& Hopkins, 2007; Leithwood \& Jantzi, 2000; Prestine \& Nelson, 2005; Waters, Marzano, \& McNulty, 2003; White, Brown, Hunt \& Klosterman, 2011). These findings help establish common agreement among educational practitioners, researchers, and policy makers that principals are an integral part of the success of schools and student learning. As school leaders, principals are in a position to shape the goals, direction and structure of schools. Consequently, their decisions and actions influence various school policies, procedures and practices that ultimately impact student outcomes.

While it has become clear the principal impacts student achievement and the success of schools, superintendents across the nation as well as professional principal organizations such as the National Association of Elementary School Principals (NAESP), the National Middle School Association (NMSA), and the National Association of Secondary School Principals (NASSP) have reported that retaining principals is more difficult now than any other time (Branch, Hanushek \& Rivkin, 2009; Chapman, 2005; Drake \& Roe, 2003; Educational Research Service, 2000). These organizations along with numerous educational researchers have pointed to the need for local, state and federal government, universities, leadership institutes, and professional education associations to develop strategies and policies to retain school principals (Chapman, 2005; Davis, Darling-Hammond, LaPointe \& Meyerson, 2005; Johnson, 2005; Norton, 2003;Rinehart, Winter, Keedy \& Bjork, 2002). Although retention rates vary by state, school type and other factors, a major concern is declining retention rates, and that those retained now serve much shorter tenures before retiring (Jacobson, 2005).

\section{Retention and the Changing Role of the Principal}

In many ways, the challenge of retaining principals can be attributed to the role of the school principal having become ill-defined to the point where one single person cannot meet the expectations of the position (Drake \& Roe, 2003; Winter \& Morganthal, 2002). Over the past several decades, the expectations of principals have become increasingly influenced by legislative and school district mandates, adding incrementally to the job responsibilities without reducing other duties (Battle \& Gruber, 2010; Pijanowski, Hewitt\& Brady, 2009; Rayfield \& Diametes, 2004; Winter, Rinehart, Keedy \& Bjork, 2007). Prior to the 1950s, the measure of a good principal was determined by his or her ability to successfully manage day-to-day operations of the school, and the emphasis was accountability for the use of 
monetary and human resources (Beck \& Murphy, 1993). During this time, a successful manager was also viewed as a good leader (Markley, 2008). Now, the role of the principalship has shifted from just being a manager to that of a multifaceted leader. Contemporary principals must navigate numerous levels of bureaucracy arising from new federal and state legislation, while also acting as instructional and transformational leaders held accountable for student outcomes (Andreyko, 2010; DeBray-Pelot \& McGuinn, 2009). A report conducted by the Educational Research Service (ERS) at the request of the National Association of Elementary School Principals (NAESP) and the National Association of Secondary School Principals (NASSP) supports this depiction of the evolving and challenging role of the principalship:

Some characterize the position as one that takes a superman or superwoman to do. There is a sense of multiple, often conflicting priorities, and the feeling that not everything can be done well. Time is fragmented; principals speak of the intense effort needed to find time to focus on important issues when there are a myriad of administrative tasks that must be done. Often, the leadership aspect of the job is shortchanged (Educational Research Service, 2000, p. 33).

\section{Retention and the Job Satisfaction of the Principal}

It has been said, "Work is one of the most absorbing things men can think and talk about. It fills the greater part of the working day. For the fortunate, it is a source of great satisfaction; for others it is the source of great grief" (Herzberg, Mausner \& Snyderman, 1959, p.3). Job satisfaction is a critical determinate of an individual's decision to stay with an organization, including principals. While the principalship has always included managerial tasks, the complexity and number of tasks required has increased significantly. The principal's role as manager has become a full-time job of creating and enforcing policy, ensuring a safe environment, overseeing discipline, completing necessary paperwork, ensuring compliance with policies and laws, responding to e-mails, and supervising extracurricular activities (DiPaola \& Tschannen-Moran, 2003; Kindt, 2008;Winter \& Morganthal, 2002). While necessary, these tasks detract from the ability of principals to engage in activities they associate with personal fulfillment and subsequent job satisfaction such as having a positive impact on students, faculty, and community (Metlife, 2001; Riley, 2006). Furthermore, because litigation or termination of employment can result from mismanagement, principals often have to prioritize management tasks (which in many cases have little or no relationship to improving student achievement) over those they identify as being personally fulfilling (Markley, 2008).

The National Association of School Boards suggests that effective principals function as "linchpins" of school improvement and are therefore the "gatekeepers" of effective school reform (Calwelti, 1999). However, retaining quality principals has become a serious challenge (Institute for Educational Leadership, 2000). The University Council for Education Administration (UCEA) asserts that "in order to build programs that support leadership for learning we must rethink and revise our practice in several areas" (Young \&Kochan, 2004, p. 121). Given the vital role principals have on the success of schools and students, it is important to identify and address the factors that contribute to their job satisfaction. 
Understanding the perceived sources of principals' satisfaction and dissatisfaction with their work provides one of the strongest sources of data for understanding how to go about rethinking and revising practice in order to retain these important individuals.

\section{Purpose and Significance}

The purpose of this study was to measure job satisfaction of head principals in Kentucky. Effective principals can impact student learning and other vital outcomes; thus, it is important to be able to retain effective school leaders. Examining the perceived sources of principals' satisfaction and dissatisfaction with their work has strong implications for policies and practices that can be implemented to increase principal retention. As such, the research questions of this study sought to uncover sources of satisfaction and dissatisfaction in the principalship.

\section{Objectives and Research Questions}

The study constructed a profile of the demographic and personal characteristics of Kentucky principals, and measured participants' satisfaction with specified job facets.

The following research questions were used to guide the study:

1) To what degree are head principals in Kentucky satisfied with economic attributes of their job?

2) To what degree are head principals in Kentucky satisfied with psychological attributes of their job?

3) To what degree are head principals in Kentucky satisfied with tasks and responsibilities associated with their job?

\section{Survey Sample}

The study surveyed all head principals (approximately $N=1,158$ ) throughout Kentucky's 174 public school districts. A total of 478 responses were collected providing a response rate of $41 \%$. Principals surveyed were $54 \%$ male and $46 \%$ female. The majority were White/Caucasian (96\%) and between the ages of 35 and 54 (77\%). A significant portion held the status of Rank I educators (83\%), and had 10 or more years of experience as professional educators (94\%). Most respondents graduated from a leadership preparation program within the past 15 years $(89 \%)$, had been a head principal for 10 years or less $(77 \%)$, and supervised student populations between 250 and 749 (79\%).

\section{Study Type and Data Analysis}

The research conducted was an exploratory study using survey research methods.

The researchers investigated principals' satisfaction with various aspects of their positions by employing a Rasch measurement model specifically designed for survey rating scales, namely the Rasch Rating Scale Model (RRSM) (Andrich, 1978).According to the RRSM the probability of a person $n$ responding in category $x$ to item $i$, is given by: 


$$
P_{x n i}=\frac{\exp \sum_{j=0}^{x}\left[\beta_{n}-\left(\delta_{i}+\tau_{j}\right)\right]}{\sum_{k=0}^{m} \exp \sum_{j=0}^{k}\left[\beta_{n}-\left(\delta_{i}+\tau_{j}\right)\right]} \quad x=0,1, \ldots, m
$$

Where $\tau_{\mathrm{o}}=0$ so that $\exp \sum_{j=0}^{0}\left[\beta_{n}-\left(\delta_{i}+\tau_{j}\right)\right]=1, \beta_{\mathrm{n}}$ is the person's position on the variable, $\delta_{\mathrm{i}} \mathrm{is}$

the scale value (difficulty to endorse) estimated for each item $i$ and $\tau_{1}, \tau_{2}, \ldots, \tau_{\mathrm{m}}$ are the $m$ response thresholds estimated for the $m+1$ rating categories.

Rasch Rating Scale Model (RRSM) (Andrich, 1978) is appropriate for Likert-scale data because it relates the amount of a person's latent trait (e.g., one's tendency to agree with a statement) to the probability of an item response on a single scale (Royal, 2011). It is only when these two elements are placed on the same scale and compared that truly meaningful inferences about person and item interactions can be made (Royal, Gilliland \&Kernick, 2014). The Rasch analysis for this study utilized Winsteps measurement software (Linacre, 2012). Winsteps estimated the parameters for the model using joint maximum likelihood estimation procedures (Wright \& Masters, 1982) and the software was used to test data-to-model fit, examine person and item measure quality, rating scale functioning, score reproducibility, and illustrate the construct hierarchy of satisfaction by way of item maps.

Data collection consisted of three phases. First, descriptive statistics were obtained to provide insights regarding those who completed the survey. Second, the psychometric properties of the instrument were evaluated and reported (survey validation). Third, inferences were made using the job satisfaction framework employed for this study and findings from the Rasch analysis.

\section{Building a Framework}

Major findings from prominent job satisfaction theories and associated theorists suggest several potential frameworks or lenses by which job satisfaction can be examined. While findings from these theories provide a holistic examination of what has previously been done, more importantly, such results provide implications for how these frameworks (or parts thereof) can be used to inform a framework specific to the investigation of the proposed research questions of this study. The next section briefly integrates key findings from relevant educational literature to further contextualize and support the framework used for this study.

Thompson, McNamara, and Hoyle (1997) conducted a meta-analysis of job satisfaction studies from the first 26 volumes of Educational Administration Quarterly. Part of this analysis included noting which, if any, theories were used by researchers examining job satisfaction and the effect sizes of the variables investigated. Thompson et al., (1997) determined predictors of job satisfaction spanned multiple categories of variables and, as such, researchers can best contribute new knowledge by investigating how categories of variables relate to, or combine to, predict job satisfaction. 
Additional findings from effect sizes support that a hierarchy of variable categories exists. Characteristics of job tasks were more significant predictors of job satisfaction than characteristics of the organization, and characteristics of the individual/workers were found to have the least impact on job satisfaction. These findings are consistent with situational model theorists such as Quarstein, McAfee and Glassman (1992) and Glisson and Durick (1988) who posit that job satisfaction is a product of multiple categories of variables. Such findings do not discredit results from studies examining a single category of variables; however, they do suggest that a deeper understanding of job satisfaction can be obtained by examining how characteristics of workers interact with those of the work itself and the organizational context in which the work is done. The next section will highlight the framework that was used to investigate these various categories of variables.

\section{Theoretical Framework}

Estimates are the foundations of systems we use to develop more advanced systems of measuring attributes as is done in the physical sciences (e.g., weight, height, temperature). Such attributes are not possible to measure until a single dimension and instrument is operationalized and accepted. Therefore, the framework addressed the multidimensional construct of job satisfaction in much the same way that has been done in the physical sciences, which is to split abstractions of a multidimensional construct into uni-dimensional variables that can become acceptable measures (Linacre, 2009).

Specifically, the framework employed for this study utilized the situational occurrences theory of job satisfaction as proposed by Quarstein et al., (1992). This theory posits that job satisfaction is influenced by two factors referred to as situational characteristics and situational occurrences. Situational characteristics may include pay, working conditions, promotional opportunities, supervision, and company policies. Quarstein et al., (1992) suggest situational characteristics are usually rather finite and stable aspects of the work environment/organization. In contrast, situational occurrences change rapidly and are those aspects of the actual tasks and work context. In this study, the researchers investigated single dimensions of principal job satisfaction categorized as either situational characteristics or situational occurrences. Table 1.1 illustrates how each of the research questions aligned with the framework, as well as the job satisfaction variables that were investigated within three categories of principal job satisfaction: (1) satisfaction with situational characteristics specific to economic variables/benefits associated with the position; (2) satisfaction with situational occurrences specific to psychological needs; and (3) satisfaction with situational occurrences representative of the actual work context including the tasks and responsibilities performed.

The survey included a total of 30 questions divided into three sections. Each section included 10 items designed to measure principals' job satisfaction in relation to a specific research question (see Table 1.1). Section one (items 1-10) corresponds to research question one, and measured principals' job satisfaction with economic attributes of their job. Section two (items 11-20) corresponds to research question two, and measured principals' job satisfaction with psychological attributes of their job. Section three (items 21-30) corresponds to research question three, and measured principals' job satisfaction with tasks and responsibilities 
associated with their job.

Table 1.1. Research Questions Aligned to Framework and Variables of Job Satisfaction

\begin{tabular}{|c|c|}
\hline Research question & Variables of job satisfaction \\
\hline \multirow{9}{*}{$\begin{array}{l}\text { 1. To what degree are head } \\
\text { principals in Kentucky satisfied } \\
\text { with economic attributes of the } \\
\text { job? }\end{array}$} & 1. Current salary \\
\hline & 2. Health/medical benefits \\
\hline & 3. Retirement benefits \\
\hline & 4. Leave time \\
\hline & 5. Vacation time \\
\hline & 6. Opportunities for professional learning \\
\hline & 7. Technology resources of school \\
\hline & 8. Condition of school facility \\
\hline & 9. Technology perks (provided with paid technology \\
\hline \multirow{4}{*}{$\begin{array}{l}\text { (Satisfaction with situational } \\
\text { characteristics specific to economic } \\
\text { variables/benefits associated with } \\
\text { the position) }\end{array}$} & devices) \\
\hline & 10. Coverage of expenses incurred while performing \\
\hline & role \\
\hline & 11. Effect job has on personal life \\
\hline \multirow{4}{*}{$\begin{array}{l}\text { 2. To what degree are head } \\
\text { principals in Kentucky satisfied } \\
\text { with psychological attributes of } \\
\text { their job? }\end{array}$} & 12. Impact I am having on students \\
\hline & 13. Feeling that what I am doing is making a \\
\hline & 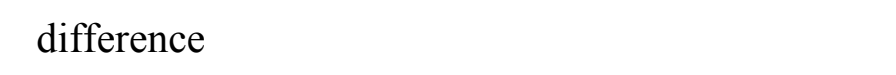 \\
\hline & 14. Recognition of my efforts by others \\
\hline \multirow{3}{*}{$\begin{array}{l}\text { (Satisfaction with situational } \\
\underline{\text { occurrences }} \text { specific to } \\
\text { psychological needs) }\end{array}$} & 15. Support from superintendent \\
\hline & 15. Support trom superintendent \\
\hline & 16. Support from central office \\
\hline \multirow[t]{2}{*}{ head } & 17. Support from teachers \\
\hline & 18. Support from the community \\
\hline
\end{tabular}


Table 1.1 (Continued). Research Questions Aligned to Framework and Variables of Job Satisfaction

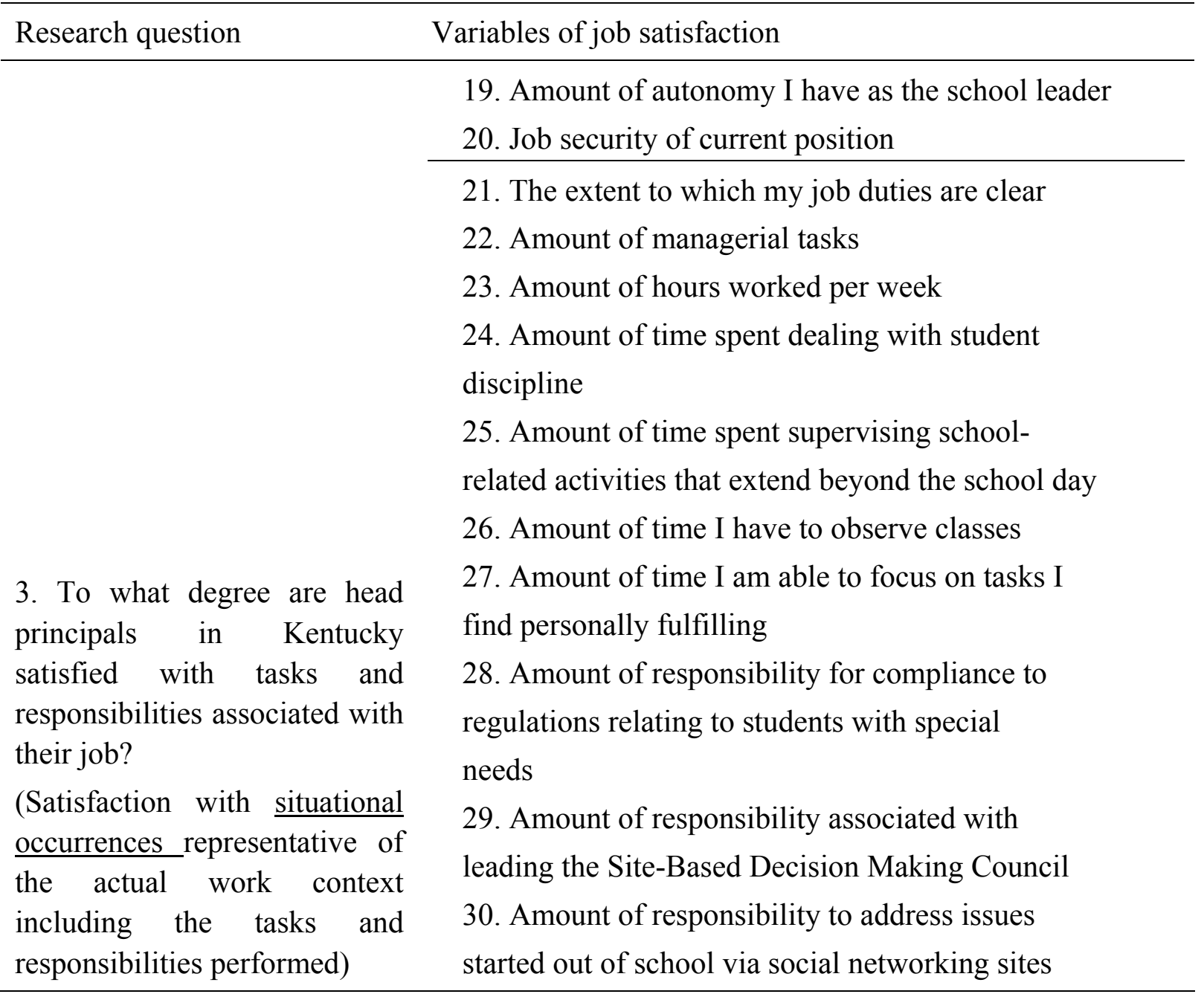

\section{Instrument}

The Principal Job Satisfaction Survey was developed by the researchers and administered via e-mail to participants using the Qualtrics survey program. The approximate time for completion of the survey was 5-10 minutes. The survey required an identification number to be entered in the title screen, and included a total of 30 questions divided into three main sections (see Table 1.1) followed by a final section of 11 demographic questions. Each question was measured using a 5-point Likert-type-scale. Participants rated their level of satisfaction with each item using a semantic differential scale. The scale ranges on a satisfaction continuum from 1-5, with 1 being "Very Dissatisfied" and 5 being "Very Satisfied". 


\section{Results}

\section{Psychometric Findings}

An important step in conducting survey research is to evaluate the quality of the instrument as it pertains to the sample, and the extent to which the data and instrument interact to produce sound and reproducible results. Construct validity is the examination and integration of any evidence which may influence the interpretation or meaning of a score (Messick, 1995). Messick's conceptualization of construct validity consists of six distinguishable aspects which can be examined to provide an informed judgment about the validity of scores. Specifically, the psychometric properties of dimensionality, reliability, rating scale effectiveness, person measure quality, item measure quality, and item hierarchy as aspects of construct validity were examined.

First, a principal components analysis of standardized residual correlations determined the Rasch dimension was both sufficient in magnitude and detection to be discernible as the primary dimension, thus meeting the requirement for uni-dimensionality. These findings provided support for the aspect of substantive validity. Structural validity was evidenced by respondents' full use of the rating scale, along with structure calibrations and category measures supporting that respondents were able to appropriately and consistently distinguish the ordinal pattern of the response options. Acceptable INFIT and OUTFIT mean-square measures and small standard errors for items supported content validity. With the exception of two items that slightly misfit the model's expectations, all other item measures conformed to Wright and Linacre's (1994) recommended range of 0.6-1.4, and standard error estimates were small and rather stable, ranging between .05 and .06 . Additionally, reliability estimates for persons (.92) and items (.99) were exceptional, thus supporting the generalizability component of validity. Systematic validity can be evaluated by performing Differential Item Functioning (DIF) analyses. The study did not investigate systematic validity, but future studies may investigate this topic. No evidence of consequential validity was presented, as future uses of score interpretations are unknown at the present time. Evidence was available to support construct validity, thus making the findings very likely to be both accurate and reproducible.

\section{Substantive Findings}

The next paragraphs summarize results for each of the research questions. Figure 1.1provides a visual representation of the results for each research question using item maps. The 10 items used to measure each research question are underlined and in bold to illustrate the relationship of these items along the entire satisfaction continuum.

When principals responded to items, they indicated their level of satisfaction using an ordinal rating scale. However, the ability to identify items on an interval scale enhances one's capability to understand a construct and recognize potential inadequacies in a given scale (Green, 1996). Using the Rasch Rating Scale Model, principals' raw ordinal data responses were converted to their natural logarithm, thereby producing interval level measures, or logits. 


\section{Macrothink

Research question 1 investigated Kentucky head principals' satisfaction with economic attributes of their jobs. Survey items Q1-Q10 were used to measure these attributes. Within this construct the most difficult item to endorse was Q9, satisfaction with technology perks (provided with paid technology devices), and the least difficult economic variable to endorse was Q3, satisfaction with retirement benefits. As can be seen in Figure 1.1, all items measuring economic job satisfaction were below the person $M$ for this sample, and only three items (Q8, Q9, and Q10) were at or above the item $M$. The data indicated that principals at or below the person $M$ in the sample did not have difficulty endorsing any of these items, or in other words, expressing satisfaction with economic job attributes.

Research question 2 investigated Kentucky head principals' satisfaction with psychological attributes of their jobs. Survey items Q11-Q20 measured these attributes (see Figure 1.1). The most difficult psychological item for principals to endorse was Q11, satisfaction with the effect job has on personal life. This item was also one of the most difficult items to endorse on the entire survey. The least difficult psychological variables included Q12, satisfaction with impact I am having on students, and item 13, satisfaction with feeling that what I am doing is making a difference. With the exception of Q11, principals at or below the person $M$ in the sample did not have difficulty endorsing items measuring psychological job attributes. In other words, besides Q11, principals generally expressed moderate to high levels of satisfaction with psychological job attributes. 


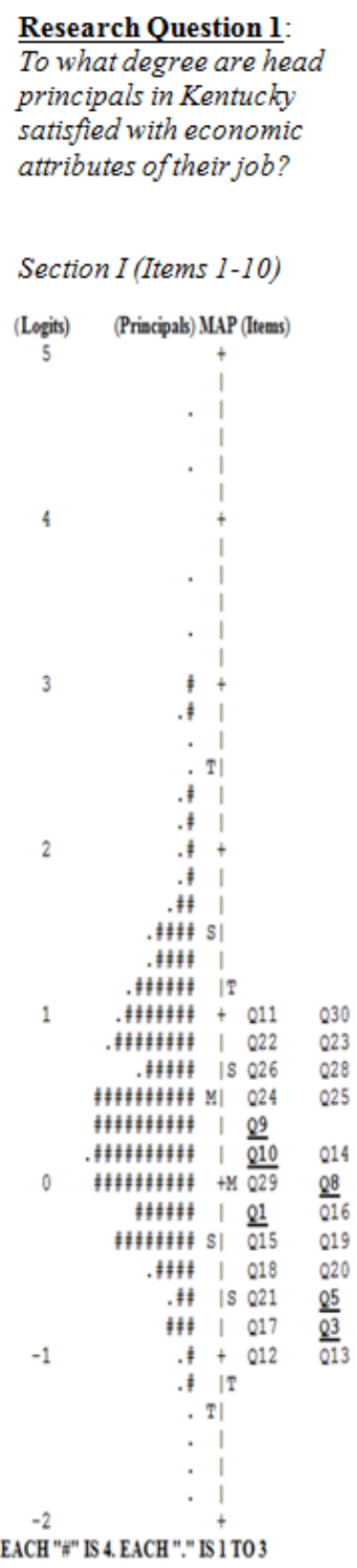

\section{Research Question 2: \\ To what degree are head principals in Kentucky satisfied with psychological attributes of their job?}

Section II (Items 11-20)

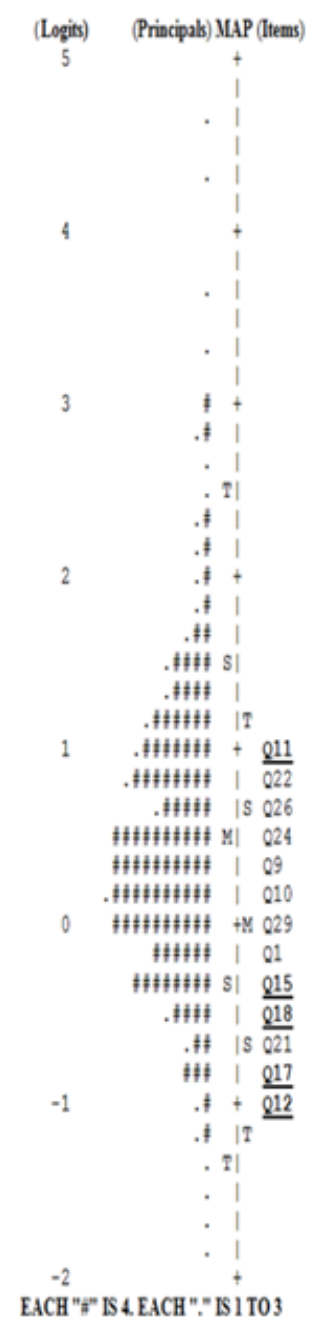

\begin{abstract}
Research Question 3:
To what degree are head principals in Kentucky satisfied with tasks and responsibilities associated with their job?
\end{abstract}

\section{Section III (Items 21-30)}

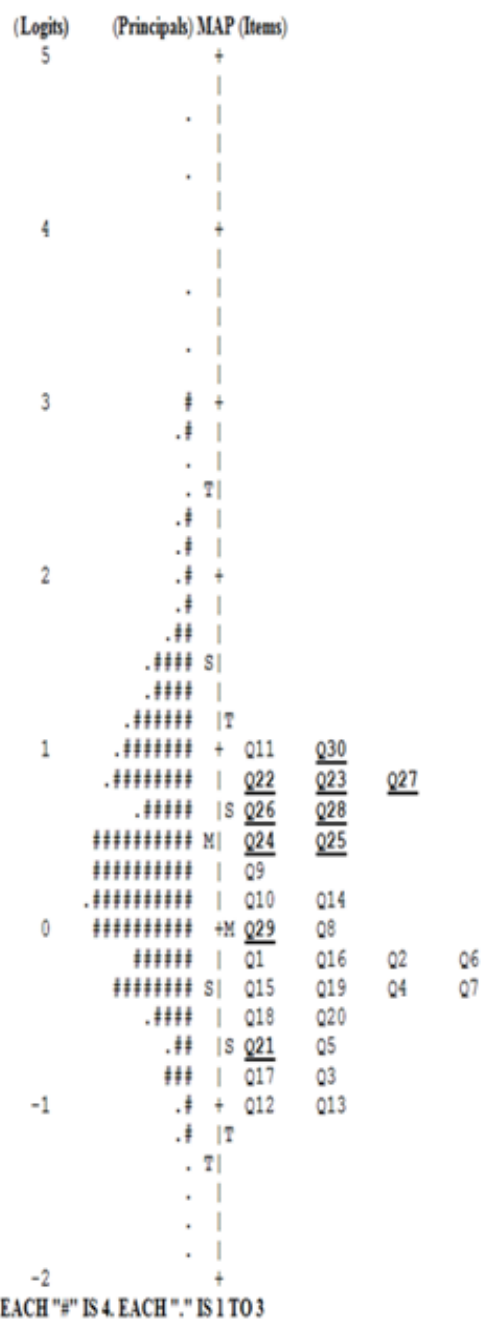

Figure 1.1. Person and Item Hierarchy Maps for Each Research Question

Research question 3 investigated Kentucky head principals' satisfaction with tasks and responsibilities of their jobs. Survey items Q21-Q30 measured principals' satisfaction with these tasks and responsibilities (see Figure 1.1). While items spanned up to two standard deviations away from the item mean, almost all items were at the top of the scale and above the person mean for this sample. As such, with the exception of Q29 and Q21, principals at or below the person $M$ in the sample expressed some level of dissatisfaction with task and responsibility job attributes. Eight of the 10 items were generally found to be strong sources of dissatisfaction for principals in this sample. These included: (a) Q30 amount of responsibility to address issues started out of school via social networking sites; (b) Q22amount of managerial tasks; (c) Q23amount of hours worked per week; (d) Q27amount 
of time I am able to focus on tasks I find personally fulfilling; (e) Q26amount of time I have to observe classes; (f) Q28amount of responsibility for compliance to regulations relating to students with special needs; (g) Q24amount of time spent dealing with student discipline; and (h) Q25amount of time spent supervising school-related activities that extend beyond the school day.

\section{Interpretation and Discussion of the Findings}

The findings of this study provided an overall hierarchy of principals' job satisfaction as well as individual hierarchies among items used to measure each of the research questions. These hierarchies provided an effective means to better understand which variables were the most significant sources of satisfaction and dissatisfaction for Kentucky head principals. An interpretation of findings will be presented for each research question in conjunction with appropriate literature in the following paragraphs.

Research question \#1.Economic job attributes were generally not significant sources of dissatisfaction for Kentucky head principals relative to the other job satisfaction categories examined. These results are consistent with the findings of content theorists such as Maslow (1954) and Herzberg (1966) who suggest that low-level extrinsic motivators (such as economic benefits) are not significant sources of satisfaction. This is not to say economic variables are unimportant when measuring job satisfaction. Instead, these findings suggest that principals in Kentucky are generally satisfied with economic attributes of their jobs, and comparatively less satisfied with psychological attributes or tasks and responsibilities.

Essentially, items measuring economic attributes provided separation among other survey items and enhanced the utility of the instrument. This yielded useful data to better understand the impact of economic attributes on principals' job satisfaction. While none of these items were significant sources of satisfaction when compared to other types of items on the survey, an examination of the item hierarchy among these economic attributes (see Table 1.2) provided a rich context for understanding this set of variables. Items at the top of the list/hierarchy are those principals are least satisfied with, and items at the bottom are those they are most satisfied with. 
Table 1.2. Hierarchal Order of Economic Job Satisfaction Variables

Research Question $\quad$ Variables of job satisfaction (least to most satisfied)

1. To what degree are head principals in Kentucky satisfied with economic attributes of their job?
Q9 Technology perks (provided with paid technology devices)

Q10 Coverage of expenses incurred while performing role

Q8 Condition of school facility

Q1 Current salary

Q2 Health/medical benefits

Q6 Opportunities for professional learning

Q4 Leave time

Q7 Technology resources of school

Q5 Vacation time

Q3 Retirement benefits

Interestingly, among economic attributes, principals in this study were generally least satisfied with Q9, Technology perks (provided with paid technology devices). The majority of existing research on principals' satisfaction with salary suggests principals are dissatisfied with their compensation (see Bowles, 1990; DeAngelis \& White, 2011; DiPaola \& Tschannen-Moran, 2003; Educational Research Service, 1998; Educational Research Service, 2000; Hancock \& Bird, 2008; McAdams, 1998; Newton, Giesen, Freeman, Bishop, \&Zeiton, 2003; Pounder \& Merrill, 2001; White, Brown, Hunt \& Klosterman, 2011). As such, it was expected that Q1, (current salary) would have been the highest ranked item in the economic hierarchy. Instead, compared to other economic attributes, Kentucky principals generally suggested they were less satisfied with the condition of their school facility, the coverage (or lack thereof) of expenses incurred while performing their role, and being provided with paid technology devices.

Q9, Technology perks (provided with paid technology devices) has not been examined in previous studies but was included to further the research base on more contemporary economic attributes of the principalship. As such, interpretations and inferences are based solely on the knowledge of the researchers. Follow-up interviews could be an effective method to obtain more insight regarding this item. Principals may have expressed dissatisfaction with technology perks due to an increased need in technology use for communication and work purposes. Throughout the workday and even after, it is expected 
that principals can be reached for emergencies or simple requests. Therefore, a principal may need to own a smartphone so he or she can be contacted via phone call, text, or email at any given time. Owning a smartphone may provide optimal communication and assist with some work tasks. However, these, and similar devices are expensive and generally not provided to principals by their employing school district.

Similarly, although principals are provided with a computer while at work, unless it is a laptop, they may feel compelled to purchase a computer and additional accessories so they can complete work tasks that demand their attention from home. Furthermore, in general satisfaction with technology perks ranked significantly lower than satisfaction with technology resources of the school. This could indicate that technology items purchased may not be readily available in the school building for personal work use. Being a contemporary principal almost necessitates having 24-hour access to various technology devices that are often expensive and not paid for by school districts. If these devices are a necessary part of principals' jobs, and principals have to purchase them, then this may be the reasoning for this particular item being at the top of the hierarchy.

The next item in the economic hierarchy (Q10) related to principals' satisfaction with coverage of expenses incurred while performing their role. Whether dissatisfaction with this variable is due to the unexpected expenses encountered performing job tasks, or those previously mentioned, Kentucky principals generally indicate this is a high level economic attribute. As with Q9, follow-up interviews could be an effective method to obtain more insight regarding this item. Similar to Q9, this item has not been examined in previous studies but was included to further the research base on more contemporary economic attributes of the principalship. As such, interpretations and inferences are based solely on the personal knowledge of the researchers.

Kentucky public school systems do not have "petty cash" funds and nearly every item purchased must be done by filling out a purchase order, which must then be approved by the district central office. This process may take one or several days. Furthermore, all items must be purchased from approved vendors unless the item is not available through an approved vendor, or if it can be proven that an alternate source is significantly less expensive than a vendor's cost. Given the immediacy of some needs that arise, principals may determine the need for a purchase outweighs the undesirable personal expense.

The last economic item at or above the item $M$ was Q8, satisfaction with condition of school facility. The average age of school buildings was 42 years in 2000, meaning some Kentucky schools may now be more than 50 years old (National Center for Education Statistics, 2000). Aging schools can present limitations for instructional programs and technology use. Kentucky superintendents responding to a survey administered by the Kentucky Legislative Research Commission (2005) indicated the condition and age of school facilities does in fact prevent school districts (and thus principals) from offering many desirable and needed instructional programs. These same superintendents point to the constant need for repairs and difficulty installing modern technology in such facilities as particularly challenging. However, given that principals generally cited high levels of satisfaction with technology resources of 


\section{Macrothink}

the school, the primary source of dissatisfaction is more likely due to the physical condition of the school facility, instead of an inability to install modern technology. Principals are held highly accountable for student outcomes, yet limitations of their school facility may prohibit access to much needed instructional programs. While principals seek ways to overcome these challenges, some principals may see the condition of their school facility as a limitation and source of dissatisfaction (White, Brown, Hunt \& Klosterman, 2011).

Research question \#2. Research question \#2 investigated the degree to which head principals in Kentucky were satisfied with psychological attributes of their job. Interestingly, besides Q11, principals generally expressed moderate to high levels of satisfaction with psychological job attributes. These data suggested that they were generally satisfied with psychological attributes of their job; however, the effect of the job on their personal lives was a strong source of dissatisfaction compared to the other survey items.

In examining the hierarchy of psychological attributes measured for research question $\# 2$, it is easily discernible that in general, principals were intrinsically satisfied with their jobs. The only item principals generally indicated being dissatisfied with was Q11, the effect the job had on their personal life. This finding suggested that something related to the job may have had an impact on principals' personal lives.

Before moving on to research question \#3, it is also important to examine the item hierarchy among psychological attributes (see Table 1.3) as this hierarchy can inform the current research base and provide a better understanding of how psychological attributes impact the job satisfaction of Kentucky head principals. 
Table 1.3. Hierarchal Order of Psychological Job Satisfaction Variables

Research Question $\quad$ Variables of job satisfaction (least to most satisfied)

2. To what degree are head Q11 Effect job has on personal life principals in Kentucky satisfied with psychological attributes of their job?

Q14 Recognition of my efforts by others

Q16 Support from central office

Q15 Support from superintendent

Q19 Amount of autonomy I have as the school leader

Q18 Support from the community

Q20 Job security of current position

Q17 Support from teachers

Q12 Impact I am having on students

Q13 Feeling that what I am doing is making a

difference

Since psychological attributes are strong determinates of job satisfaction, it can be inferred from the data that some higher level intrinsic needs and values of Kentucky head principals are being fulfilled. Given the significant impact school leaders have on student outcomes and organizational function, it is encouraging that in general Kentucky head principals reported high levels of intrinsic job satisfaction. When intrinsically fulfilled by their work, individuals (or in this case principals) are effectively motivated to perform at high levels and exert significant effort (Herzberg, 1966).

When principals feel valued and are recognized for their efforts it can be a significant source of gratification and satisfaction (Sodoma\& Else, 2009). Recognition of principals' efforts was the only other item above the item $M$, but it was still below the person $M$. As such, it was generally not a significant source of dissatisfaction for most principals in this sample. The rest of the items were below both the person and item $M$, and provide a few additional inferences.

When looking at the level of satisfaction principals have with the support they receive, it can be seen that a hierarchy exists here as well (teachers, community, superintendent, central office). Essentially, this hierarchy indicates that in general principals feel most supported by those they work and interact with most frequently. Next, and very importantly, Kentucky principals indicated a general sense of autonomy and job security. This suggests they are able to act autonomously as the school leader without constantly worrying about job security. Lastly, items Q12 and Q13 clearly indicate that Kentucky head principals are generally very 
satisfied with the impact they are having on students, and feel their efforts are truly making a difference.

Research question \#3. Research question \#3 measured the degree to which head principals in Kentucky were satisfied with tasks and responsibilities of their jobs (see Table 1.4). With the exception of two items (Q29 and Q21), nearly all of the items measuring satisfaction with tasks and responsibilities were at the top of the scale and above the person $M$ for this sample. These results indicated that in general, the greatest sources of dissatisfaction for Kentucky head principals in this sample related to the tasks and responsibilities of their job. These findings are consistent with prominent job satisfaction theorists such as Glisson and Durick (1988) who suggest that categories of variables, and especially characteristics of job tasks, are excellent predictors of satisfaction and organizational commitment.

Table 1.4. Hierarchal Order of Task and Responsibility Job Satisfaction Variables

Research Question

Variables of job satisfaction (least to most satisfied)

3. To what degree are head principals in Kentucky satisfied with tasks and responsibilities associated with their job?

Q30 Amount of responsibility to address issues started out of school via social networking sites Q22 Amount of managerial tasks Q23 Amount of hours worked per week Q27 Amount of time I am able to focus on tasks I find personally fulfilling

Q26 Amount of time I have to observe classes

Q28 Amount of responsibility for compliance to regulations relating to students with special needs Q24 Amount of time spent dealing with student discipline

Q25 Amount of time spent supervising school-related activities that extend beyond the school day Q29 Amount of responsibility associated with leading the Site-Based Decision Making Council

Q21 The extent to which my job duties are clear

Interestingly, among tasks and responsibilities, principals in this study were generally least satisfied with Q30 (Amount of responsibility to address issues started out of school via social networking sites). This item has not been examined in previous studies. However, it was 
included to further the research base on contemporary responsibilities in the principalship.

The responsibilities of the principalship are continually expanding to adapt to contemporary issues and technologies. This now includes the widespread use of social networking sites by students. Principals have a legal responsibility to investigate any threats or forms of abuse brought to their attention that could interfere with safety or the normal continuation of the school day (Kentucky Revised Statute 158.156, 2008). The use of social networking sites, even after school hours or off school property can cause concerns for safety and/or disrupt the regular school day. Common examples include students posting threats to others or themselves, or even students and teachers engaging in inappropriate communications. Regardless of the actual facts in a given situation, principals are legally accountable to investigate any such instances. Such investigations can consume considerable time and resources. Kentucky principals generally seem to indicate this issue is a significant source of dissatisfaction.

The next two items in the hierarchy included principals' satisfaction with the amount of managerial tasks and hours worked per week. Principals can expect to work on both evenings and weekends with average workweeks between 54-80 hours (Educational Research Service, 2000; Yerkes \& Guaglianone, 1998). Many of these hours are spent on managerial tasks and have little or nothing to do with the primary job of the principal, which is to improve student outcomes. As such, it is not unreasonable that principals generally cited managerial tasks such as Q24 (Amount of time spent dealing with student discipline) and Q25 (Amount of time spent supervising school-related activities that extend beyond the school day) as being important sources of dissatisfaction.

Dealing directly with student discipline may consume several hours each day. More severe cases that involve criminal acts, violence, or drugs can take away up to an entire day of a principal's time which otherwise could have been utilized acting in the role of an instructional leader (Markley, 2008). The additional time spent after school supervising extracurricular activities has also been cited as a major source of dissatisfaction, and is often seen by principals as an irrelevant extension of an already long workday (Brogan, Matthews, \& Neill, 2005).

The amount of time principals spend on managerial tasks detracts from tasks associated with improving student outcomes and some that principals have cited as providing intrinsic satisfaction. These account for several additional items in the hierarchy such as: Q28, Amount of responsibility for compliance to regulations relating to students with special needs; Q26, Amount of time I have to observe classes; Q27, Amount of time I am able to focus on tasks I find personally fulfilling; and Q29, Amount of responsibility associated with leading the Site-Based Decision Making Council.

Many principals may not feel they have the expertise to oversee the development and refining of Individualized Education Plans for students with special needs, and might instead prefer this task be delegated to a professional who can oversee this process and ensure the school is in compliance (Markley, 2008). Given the high legal stakes of accountability for compliance to special education law and implementation, it is possible that principals feel their limited 
expertise in such an area does not qualify them for the amount of responsibility and oversight they are expected to provide. Instead, principals feel more qualified as instructional leaders observing classrooms and gaining a better understanding of students' needs. Engaging in tasks where principals are directly developing relationships with teachers and students to improve school climate and student achievement are found to be important sources of satisfaction (DiPaola\&Tschannen-Moran, 2003).

Ironically, the only item examined in research question \#3 below the item $M$ was Q21 (The extent to which my job duties are clear). So, in general, Kentucky principals do indicate their job duties are clear. However, what is not clear is why they are asked to engage in so many tasks that potentially have negative impacts on their job satisfaction and detract from the time needed to focus on their primary responsibility to improve student outcomes.

\section{Implications for Practice}

The findings of this study provide several useful insights regarding the job satisfaction of Kentucky head principals and what can be done to retain these important individuals.

Essentially, data in this study indicatethat head principals in Kentucky are generally: (a) dissatisfied with the amount of hours they work (which may explain the dissatisfaction with the effect of the job on their personal life); (b) dissatisfied with the amount of time spent on tasks that have nothing to do with their primary responsibility of improving student outcomes; and (c) dissatisfied with the lack of time they are able to spend on tasks that are directly related to improving student outcomes. These findings suggest that similar to a study of Kentucky principals by Riley (2006) "there may be an inherent conflict between the highest priority of reform in Kentucky (i.e., improved instruction and better student performance on standardized achievement tests) and non-instructional principal duties" (p. 203).

If superintendents and policy makers want to retain principals in Kentucky then they need to address these legitimate sources of dissatisfaction. A major starting point is to consider how to define the primary job of principals. Principals are hired for the purpose of, held accountable for, and dismissed based on their ability (or inability) to improve student outcomes. As such, the primary job responsibility of principals should be focused on this task. However, studies on how principals use their time have found that 26 hours of their work week are spent on management and administrative tasks, and only 17 hours are spent on instruction (White, Brown, Hunt, \& Klosterman, 2011).

These aforementioned findings and those from this study clearly indicate a crucial barrier principals face in improving student outcomes is due to how inefficiently their time is used. Kentucky head principals are generally dissatisfied with the amount of hours they work, which is likely a result of spending too much time on tasks that have nothing to do with improving student outcomes, and too little time on tasks that are directly related to improving student outcomes. As such, a primary implication of this research is that Kentucky policy makers and superintendents could simultaneously increase principal retention and student outcomes by addressing these inefficiencies. 


\section{Limitations}

The study had several potential limitations. First, results were limited to public elementary, middle, and high school principals in Kentucky who were willing to participate in the survey (41\%). Also, principals of private, parochial, vocational, and alternative schools were excluded, and therefore not represented.

Next, results were presented as a census sample, and findings were generalized to all Kentucky head principals. Results were not disaggregated by school level (elementary, middle, high) or person demographics. As such, no generalizations were made regarding differences in school/organizational characteristics or the demographics of respondents. Such results may have provided interesting insights among school levels, geographical locations, and the personal characteristics of respondents.

Additionally, to the knowledge of the researchers, no previous studies of principal job satisfaction have employed Rasch methods to analyze data. This presented a potential limitation due to an inability to methodologically compare this study with existing studies. Although there were some limitations for comparing methodologies, the results and findings from this study were still able to be used to make comparisons with existing research.

A final limitation to acknowledge was this study only looked at job satisfaction to inform principal retention. Investigating job satisfaction of principals is not the only means to address retention. Other approaches and methods may exist.

\section{Suggestions for Future Research}

The findings of this study provide several suggestions for future principal job satisfaction and retention research:

1) Job satisfaction instruments need to be specific to the jobs they are intended to measure. Many principal job satisfaction studies have utilized the Minnesota Satisfaction Questionnaire (MSQ), Job Description Index (JDI), and Job Diagnostics Survey (JDS). While these instruments have provided significant contributions, a potential limitation is that these instruments only investigate broad dimensions of worker satisfaction, and are not specific to any single job. As such, when using these instruments to investigate the job satisfaction of principals, findings can potentially be misleading. For example, if a researcher used the MSQ with principals and a majority of the sample responded that they are satisfied with "the responsibility of my job," then what can truly be inferred? If asked to rate their satisfaction with "the responsibility to address complaints of angry parents" would respondents have provided a different response? Items specific to the principalship are needed to more accurately determine which responsibilities of the job are sources of satisfaction or dissatisfaction.

2) Future principal job satisfaction instruments should continually integrate items that represent contemporary issues in the principalship. As was found in this study, the item principals generally had the most difficulty endorsing was satisfaction with was a contemporary issue (responsibility to address issues started outside of school via social 
networking sites). Also, while not significant sources of job satisfaction, two new economic attributes introduced in this study were the highest ranking items in the economic subscale (satisfaction with technology perks/provided with paid technology devices; and, coverage of expenses incurred while performing role). Each of these items provided new contributions to the literature on principal job satisfaction.

3) Findings from this study indicate principals in this sample were generally more likely to express dissatisfaction with tasks and responsibilities of their work than economic or psychological attributes. As such, future studies should further investigate specific tasks and responsibilities as these variables are generally significant sources of dissatisfaction.

4) Whilesurvey research on principal job satisfaction has provided considerable contributions to the literature, much of this research has been limited to traditional statistical methods. Commonly, these researchers administered some form of rating scale instrument to a given sample to measure levels of job satisfaction. Once data were collected, it was typically summed and averaged and the subsequent results were presented as descriptive and/or inferential statistics. What these researchers fail to realize when doing this is that they are treating ordinal data as if it were interval. Ordinal raw score data only indicate that one response option is more or less than another response option. These numbers and ranks are not measures. For such numbers or ranks to become measures, they must be converted into a linear continuum that possesses equal distances between each of the units (Bond \& Fox, 2007). Until data have been linearized on a calibrated 'ruler' or 'scale' to conduct measurements, any assertions made about the results may be based on problematic methodological assumptions and, consequently, may be invalid. While traditional methods are useful for some purposes, future studies should consider utilizing Rasch models as they arguably provide a more thorough and methodologically sound approach to survey research.

\section{Conclusion}

Effective principals can impact student learning and other vital outcomes. Therefore, it is important to be able to retain effective school leaders. Examining the perceived sources of principals' satisfaction and dissatisfaction with their work has strong implications for policies and practices that can be implemented to increase principal retention. As such, the purpose of this study was to measure the job satisfaction of head principals in Kentucky.

Compared to the two other categories of job satisfaction measured, economic job attributes were found to have the least impact on the job satisfaction of principals in this sample. Next, principals examined indicated they were generally satisfied with the psychological job attributes measured with the exception of one variable, the effect of the job on their personal life. Major findings from data in this study indicated that head principals in Kentucky were generally: (a) dissatisfied with the amount of hours they work; (b) dissatisfied with the amount of time spent on tasks that have nothing to do with their primary responsibility of improving student outcomes; and (c) dissatisfied with the lack of time they are able to spend on tasks that are directly related to improving student outcomes. A primary implication of this research was that Kentucky policy makers and superintendents could simultaneously increase principal retention and student outcomes by implementing strategies designed to 
minimize or eliminate managerial responsibilities from the principalship so principals can instead focus on being instructional leaders.

\section{References}

Aberli, T. (2010). Job satisfaction and professional growth experiences of urban school administrators. (Doctoral dissertation). Retrieved from ProQuest Dissertations and Theses database. (UMI No. 3472537).

Andreyko, T. (2010). Principal leadership in the accountability era: Influence of expanding job responsibilities on functional work performance, stress management, and overall job satisfaction. Retrieved from ProQuest Dissertations and Theses database. (UMI No. 3447305).

Andrich, D. (1978). A rating formulation for ordered response categories. Psychometrica, 43, 561-573. http://dx.doi.org/10.1007/bf02293814.

Battle, D., \& Gruber, K. (2010). Principal attrition and mobility: Results from the 2008-2009 Principal Follow-up Survey (NCES 2010-337). U.S. Department of Education, National Center for Education Statistics. Washington, DC: U.S. Government Printing Office.

Beck, L., \& Murphy, J. (1993). Understanding the principalship: Metaphorical themes, 1920s-1990s. New York, NY: Teachers College Press.

Bond, T., \& Fox, C. (2007). Applying the Rasch Model: Fundamental measurement in the human sciences. ( $2^{\text {nd }}$ ed.). Lawrence Erlbaum Associates, Inc. http://dx.doi.org/10.4324/9781410614575.

Bowles, B. (1990). The silent crisis in educational leadership. The Education Digest, 53, 12-14.

Branch, G., Hanushek, E., \& Rivkin, S. (2009). Estimating principal effectiveness. (Working paper 38). Washington, DC: CALDER, The Urban Institute.

Brogan, G., Mathews, J., \& Neill, M. (2005). Is the principalship in peril? Task performance factors effecting job satisfaction of high school principals in a mountain west state. Journal for Effective Schools, 4(1), 47-63.

Cawelti, G. (1999). Improving student achievement: Finding research-based practices that boost student achievement. The American School Board Journal, 186(7), 34-47.

Chapman, J. (2005). Recruitment, retention, and development of school principals. International Academy of Education, International Institute for Educational Planning, 1-37.

Council of Chief State School Officers. (1996). Interstate School Leaders Licensure Consortium: Standards for School Leaders. Washington, DC: author.

Davis, S., Darling-Hammond, L., LaPointe, M., \& Meyerson, D. (2005).School leadership study: Developing successful principals (Review of Research). Stanford, CA: Stanford University, Stanford Educational Leadership Institute. 
DeAngelis, K., \& White, B. (2011). Principal turnover in Illinois public schools, 2001-2008. Illinois Education Research Council, 1-28.

Debray-Pelot, E., \& McGuinn, P. (2009). The new politics of education: Analyzing the federal education policy landscape in the post-NCLB era. Educational Policy, 23(1), 15-42. http://dx.doi.org/10.1177/0895904808328524.

DiPaola, M., \&Tschannen-Moran, M. (2003). The principalship at a crossroads: A study of the conditions and concerns of principals. National Association of Secondary School Principals, 87(643), 43-65. http://dx.doi.org/10.1177/019263650308763404.

Drake, T., \& Roe, W. (2003). The principalship (6th ed.). Upper Saddle River, New Jersey: Merrill Prentice Hall.

Educational Research Service. (1998). Is there a shortage of qualified candidates for openings in the principalship? An exploratory study. Arlington, VA: Author.

Educational Research Service. (2000). The principal, keystone of a high-achieving school: Attracting and keeping the leaders we need. Washington, DC: National Association of Elementary School Principals and National Association of Secondary School Principals.

Fuller, E., \& Young, M. (2009). Tenure and retention of newly hired principals in Texas.Texas High School Project Leadership Initiative. Issue Brief 1. University of Texas at Austin.

Glisson, C., \& Durick, M. (1988). Predictors of job satisfaction and organizational commitment in the human services organizations. Administrative Science Quarterly, 33(1), 61-81. http://dx.doi.org/10.2307/2392855.

Green, K. (1996). Applications of the Rasch model to evaluation of survey data quality. New Directions for Evaluation, 70, 81-92. San Francisco: Jossey-Bass. http://dx.doi.org/10.1002/ev.1036.

Hallinger, P., \& Heck, R. (1996). Reassessing the principal's role in school effectiveness: A review of empirical research, 1980-1995. Educational Administration Quarterly, 32(1), 5-44. http://dx.doi.org/10.1177/0013161x96032001002.

Hancock, D., \& Bird, J. (2008). Motivators and inhibitors to becoming a school leader.Annual Meeting of the American Educational Research Association, New York.

Heck, R., \& Hallinger, P. (1999). Conceptual models, methodology, and methods for studying school leadership. In J. Murphy \& Seashore-Louis (Eds.), The $2^{\text {nd }}$ handbook of research in educational administration. San Francisco: McCutchan.

Herzberg, F., Mausner, B., \& Snyderman, B. (1959). The motivation to work (2nd ed.).New York: John Wiley \& Sons.

Herzberg, F. (1966). Work and the nature of man. New York: World Publishing.

Institute for Educational Leadership. (2000). Leadership for student learning: Reinventing the 
principalship. A report of the task force on the principalship. Washington, D.C.

Jacobson, S. (2005). The recruitment and retention of school leaders: Understanding administrator supply and demand. In Bascia, N., Cumming, A., Datnow, A., Leithwood, K., \& Livingstone, D. (Eds.), International handbook of educational policy (pp. 457-470). Great Britain: Springer Press.

Johnson, L. (2005). Politics and the principalship: Why principals quit. A brief published by The National Association of Elementary School Principals, 21-23.

Kentucky Legislative Research Commission. (2005). A review of the school facilities construction commission. Kentucky Education Assessment and Accountability.

Kentucky Revised Statute (KRS 158.156). (2008). Reporting of commission of felony Chapter 508 offense against a student. http://www.lrc.ky.gov/Statutes/statute.aspx?id=3455.

Kindt, C. (2008). Relationship between organizational climate and job satisfaction among middle school principals in central Florida. (Doctoral dissertation). Retrieved from ProQuest Dissertations and Theses database. (UMI No. 3322928).

Leithwood, K. (1994). Leadership for school restructuring.Educational Administration Quarterly, 20(4), 498-518. http://dx.doi.org/10.1177/0013161x94030004006.

Leithwood, K., Harris, A., Day, C., Sammons, P., \& Hopkins, D. (2007). Distributed leadership and organizational change: Reviewing the evidence. Journal of Education Change, 8(4), 337-347. http://dx.doi.org/10.1007/s10833-007-9048-4.

Leithwood, K., \&Jantzi, D. (2000). Principal and teacher leader effects: A replication. School Leadership and Management, 20(4), 415-434. http://dx.doi.org/10.1080/713696963.

Linacre, M. (2009). Unidimensional models in a multidimensional world. Rasch Measurement Transactions, 23(2), p. 1209. http://www.rasch.org/rmt/rmt232d.htm.

Linacre, M. (2012). Winsteps and Facets Rasch software.Winsteps Software Index. http://www.winsteps.com/index.htm.

Markley, D. (2008). The changing roles and responsibilities of the high school principal. (Doctoral dissertation). Retrieved from ProQuest Dissertations and Theses database. (UMI No. 3363771).

Maslow, A. (1954). Motivation and personality. New York: Harper \& Row.

McAdams, R. (1998). Who'll run the schools? The American School Board Journal, 29(8), 37-39.

Messick, S. (1995). Validity of psychological measurement: Validation of interferences from persons' responses and performances as scientific inquiry into score meaning. American Psychological Association, 50(9), 741-749.

Metropolitan Life Insurance Company. (2001). Key elements of quality schools: A survey of teachers, students, and principals. NY: The Metlife Survey of the American Teacher. 
National Center for Education Statistics. (2000). Condition of America's public school facilities: 1999. U.S. Department of Education, Office of Educational Research and Improvement.

Newton, R., Giesen, J., Freeman, J., Bishop, H., \&Zeitoun, P. (2003). Assessing the reactions of men and women to attributes of the principalship. Educational Administration Quarterly, 39(4), 505-531. http://dx.doi.org/10.1177/0013161x03255193.

Norton, M. (2003). Let's keep our quality school principals on the job. The High School Journal, 86(2), 50-56. http://dx.doi.org/10.1353/hsj.2002.0024.

Pijanowski, J., Hewitt, P., \& Brady, K. (2009). National Association of Secondary School Principals, 93(2), 85-95.

Pounder, D., \& Merrill, R. (2001). Job desirability of the high school principalship: A job choice theory perspective. Educational Administration Quarterly, 37(1), 27-57. http://dx.doi.org/10.1177/00131610121969235.

Prestine, N., \& Nelson, B. (2005). How can educational leaders support and promote teaching and learning? New conceptions of learning and leading in schools. In W.A. Firestone \&C. Riehl (Eds.), A New Agenda for Research in Educational Leadership (pp.46-60). New York: Teachers College Press.

Quarstein, V., McAfee, R., \& Glassman, M. (1992).The situational occurrences theory of job satisfaction.Human Relations, $\quad$ 85(8), http://dx.doi.org/10.1177/001872679204500806.

Rayfield, R., \& Diamantes, T. (2004). Task analysis of the duties performed in secondary school administration. Journal of Instructional Psychology, 31(3), 253-256.

Riley, V. (2006).Predictors of principal job satisfaction in a reform state: Effects of general job facets and principal job-specific facets. (Doctoral dissertation). Retrieved from ProQuest Dissertations and Theses database. (UMI No. 3234255).

Rinehart, J., Winter, P., Keedy, J., \& Bjork, L. (2002). State action for educational leadership policy (SAELP) principal survey report. Kentucky Department of Education.

Royal, K. (2010).Making meaningful measurement in survey research: A demonstration of the utility of the Rasch model. IR Applications, 28, 1-16.

Royal, K., Gilliland, K., \&Kernick, E. (2014). Using Rasch measurement to score, evaluate, and improve examinations in an anatomy course. Anatomical Sciences Education, 7(6), 450-460. http://dx.doi.org/10.1002/ase.1436.

Sodoma, B., \& Else, D. (2009).Job satisfaction of Iowa public school principals.The Rural Educator, 31(1), 10-18.

Thompson, D., McNamara, J., \& Hoyle, J. (1997). Job satisfaction in education organizations: A synthesis of research findings. Educational Administration Quarterly, 33(1), 7-37. http://dx.doi.org/10.1177/0013161x97033001002. 
Waters, T., Marzano, R., \& McNulty, B. (2003). Balanced leadership: What 30 years of research tells us about the effect of leadership on student achievement. Aurora, $\mathrm{CO}$ : Mid-Continent Research for Education and Learning.

White, B., Brown, E., Hunt, E., \& Klostermann, B. (2011). The view from the principal's office: Results from the IERC principals survey (IERC 2011-12). Edwardsville, IL: Illinois Education Research Council, (1-40). Accessed at http://ierc.siue.edu.

Winter, P., Rinehart, J., Keedy, J., \& Bjork, L. (2007). Superintendent recruitment: A statewide assessment of principal attraction to the job. Planning and Changing, 38(1\&2), $35-59$.

Winter, P., \& Morgenthal, J. (2002). Principal recruitment in a reform environment: Effects of school achievement and school level on applicant attraction to the job. Educational Administration Quarterly, 38(3), 319-340.http://dx.doi.org/10.1177/00161x02038003003.

Wright, B., \& Linacre, J. (1994). Reasonable mean-square fit values. Rasch Measurement Transactions, 8(3), 370 .

Yerkes, D., \& Guaglianone, D. (1998). Where have all the high school administrators gone? Thrust for Educational Leadership, 28, 10-14.

Young, M., \& Kochan, F. (2004). UCEA leaders respond: Supporting leadership for America's schools. Better leaders for America's schools: Perspectives on the manifesto. pp. 115-129. Columbia, MO: University Council for Educational Administration. 